\title{
WATER AND ENVIRONMENTAL SECURITY IN THE MIDDLE EAST
}

\author{
J. David Rogers \\ University of Missouri-Rolla
}

\begin{abstract}
Israel, Jordan and the Palestinian Authority are linked by common aquifers that have recently become subject to overdrafting, contamination and negotiation. The present shortage followed a period of unprecedented exploration and exploitation of their water resources, with the Israelis using military force to secure their principal source watershed. The

environmental security of the region's scarce water resources has become a contentious issue and an impediment to regional development because the three entities have been unable to develop protocols for managing their natural resources.

In the near future, survivability in the harsh climate of the Middle East will be driven by economic sustainability and environmental security. The most challenging aspect of expanding populations in Israel, Jordan and the Palestinian Authority will be finding sufficient supplies of potable water. Water is fundamental to sustainability of life, for bodily intake and maintenance of sanitation. A significant fraction of new water sources will inevitably come from desalination of sea water using reverse osmosis, which requires significant capital outlay and electrical power. Water resource management has emerged as a national priority upon which each country sees its survival depending. Armed conflicts and sporadic clashes will continue if the issue is not resolved.
\end{abstract}

\section{INTRODUCTION}

Israel and the Palestinian Territories are separated from Jordan by the Syrian-African Rift, the longest valley in the world (Figs. 1 and 2). The three nations are linked by common aquifers, but their groundwater reserves have been over utilized for crop production, even when many foodstuffs might be imported at lower unit prices. Since the mid-1980s, the expanding populations of Israel, Jordan, and the Palestinian Authority have found themselves competing for dwindling water resources.

Middle East population growth is currently averaging a staggering 3 percent annually. The population of Israel and the Palestinian Territories now stands at approximately 8 million. The population of the Palestinian Authority occupying Gaza and West Bank recently exceeded 1.5 million. Israel's 


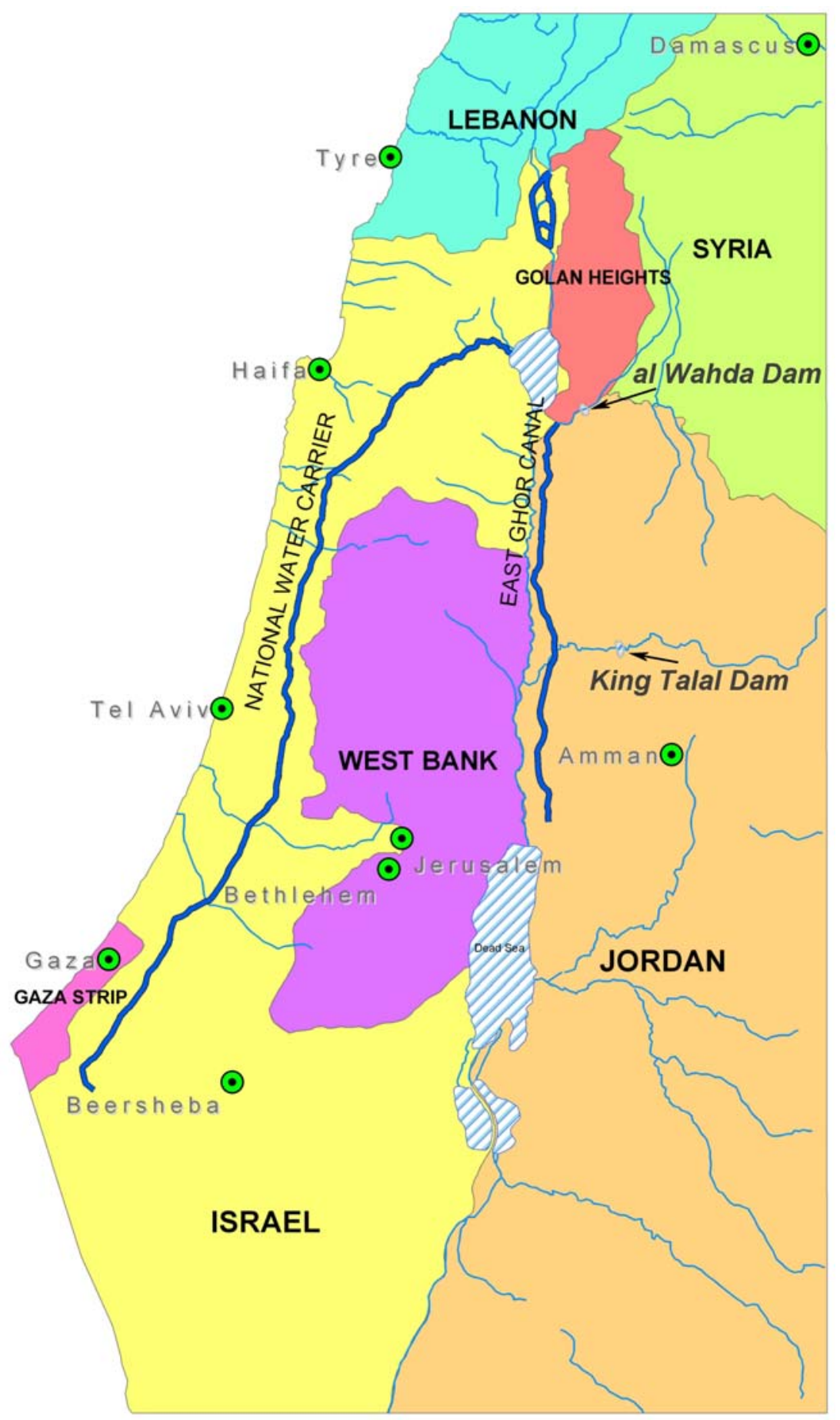

Figure 1 - Map of border region between Israel, Jordan and the Palestinian Authority, showing the Golan Heights, the National Water Carrier, the East Gohr Canal and the proposed al Wahda Dam site. 
growth has come about in large part through three waves of immigration: the first following establishment of the British mandate at end of First World War (1918); a second pulse after the Second World War, particularly 1948, when the State of Israel was created; and a more recent influx of immigrants between 1987-2002, when 2 million Russian Jews settled in Israel. By 2020 the population of Israel is expected to grow to 9 million and that of the Palestinian Authority to exceed 3 million.

According to the World Bank, the Middle East has the highest median cost of water supply and sanitation in the world, reaching \$300 per capita in 1985, about double what it costs in the United States and about five times the cost of water in Southeast Asia (Starr, 1991). Israel, the Palestinian lands (West Bank and Gaza), and Jordan are jointly facing a combined water deficit of at least 300 to $400 \mathrm{~m}^{3}$ per year, and as much as 500 to 600 million $\mathrm{m}^{3}$, depending on weather patterns and consumption (Casa, 1991). Jordan's population is increasing at a rate of $3.8 \%$ per year, one of the world's highest growth rates. Like Israel, Jordan has exhausted her natural water resources and must begin looking seriously at desalination and water import schemes to meet future demands.

Security concerns have been an impediment to cooperative resource development by Israel and her neighbor Arab states since the creation of Israel in 1948. The Israelis are concerned that their water resources infrastructure is secure from intervention and terrorism. Armed conflict erupted between Israel and Syria in 1964-65 when Syria attempted to divert flow from the upper Jordan River (Gleick, 1993). Israeli concerns about their environmental security manifest themselves again in the June 1967 war, when Israel doubled their water resources by occupying the Golan Heights and south Mt. Herman, where the waters of the Jordan River coalesce. Israel has refused to relinquish any of this valuable watershed.

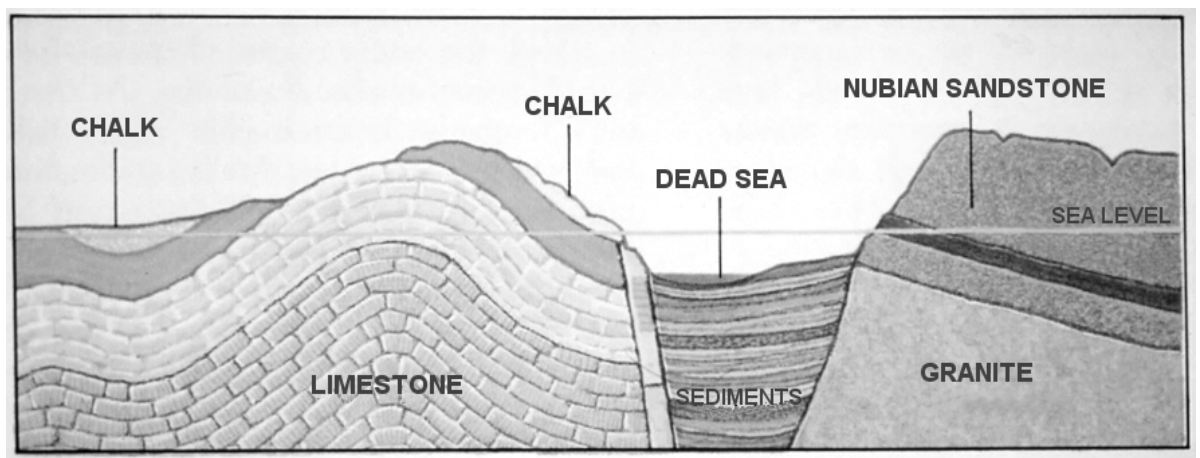

Figure 2 - Generalized geologic section through the Syrian-African Rift, between Israel and the West Bank territory on the left and Jordan on the right. The Dead Sea occupies the lowest point in a massive graben formed by a pull-apart basin between the Mediterranean and Arabian tectonic plates (modified from Beitzel, 1985). 
The Palestinian Authority has the greatest need for developing additional sources of water, but no formal agreement has been reached on this issue in the ongoing negotiations with Israel because of the overpowering concerns about security which erupted when the Infantada began in 1999. Development of new water sources has become a bargaining chip for Israel and the Palestinian Authority their ongoing negotiations. The region's Arab neighbors see America as the only peace broker, capable of funding key infrastructure improvements on the west bank that the Israelis would refrain from targeting in any retaliatory strikes. Water has emerged as the key component in the region's environmental security. Exploitation of water resources will reign supreme in any economic development in this volatile region in the foreseeable future.

\section{DEVELOPMENT OF WATER RESOURCES}

The first modern water conveyance system in the region was initiated by Jewish settlers in 1935 to bring well water from the Jezreel Valley southward through Palestine, when it was a British mandate, to the northern Negev Desert. Jewish settlers constructed three experimental settlements in the Negev in 1943, followed by 16 more in 1946-47. This first water pipeline leading to the northwestern Negev was only $0.15 \mathrm{~m}$ diameter, but stretched $190 \mathrm{~km}$. It was completed in 1947. The first large-scale supply system was a $1.68 \mathrm{~m}$ diameter pipeline extending $130 \mathrm{~km}$ from the Yarkon River to the Negev completed by the Israelis in 1948. It was capable of supplying 100 million $\mathrm{m}^{3} / \mathrm{yr}$.

In the late 1950s Jordan and Israel embarked on a race to collect, convey, and disperse the free-flowing waters of the Jordan River below the Sea of Galilee. In 1955 the Johnston Unified Water Plan was adopted by both countries as a non-ratified treaty of allocation rights, which was more or less successfully implemented until the June 1967 war between Israel and her Arab neighbors (Efrati, 2000). By 1961 the Jordanians completed their 110$\mathrm{km}$ long East Ghor Canal in the Jordan Valley below the Sea of Galilee (the name was changed to the King Abdullah Canal in 2001). During the decade of the 1960s the Israelis constructed their National Water Carrier, an 85 kmlong system of pipelines, open channels, tunnels, re-regulation pools and distribution reservoirs (Kantor, 2001).

In 1964 the Arab League countries tried to sabotage the Israeli system by diverting water from the Jordan River just downstream of the Sea of Galilee. The Israelis responded by moving their intake to the northwestern shore of Galilee, near Tabgha, further from the border. The Israelis changed their plan so a $372 \mathrm{~m}$ lift would be required at the intake, from whence the flow would be taken by gravity to Israel's coastal plain. When they realized that the Israelis were proceeding with construction of the Tabgha intake, the 
Syrians began diverting the headwaters of the Jordan River during the winter of 1964-65. The Israelis responded with a series of air strikes and commando raids on Syria's diversion works (Gleick, 1993). This military action contributed to the tensions that led to the June 1967 war, when Israel secured the Golan Heights and Mt. Herman, effectively doubling its domestic water supply (shown as the Golan Heights occupation zone in Fig. 1). The National Water Carrier is often referred to as the Kinneret-Negev Conduit, and was constructed between 1964-69. Subsequent extensions and cross-overs have been added to the conduit on a near-continuous basis, and water is pumped, in stages, to the kibbutzim in the northwestern Negev.

Since completion of the National Water Carrier distribution system, Israel has augmented its conveyance capacity by drilling hundreds of wells to tap groundwater resources along the route, so that they presently convey around 400 million $\mathrm{m}^{3} / \mathrm{yr}$, which supplies about $25 \%$ of Israel's needs. In January 1990 and the summer of 1991 the water carrier was shut down by drought and deliveries to agricultural users were slashed 50\%. This sudden cessation of water deliveries brought international attention to how tenuous the water situation had become in the face of Israel's commitment to allow two million Russian Jews to immigrate during the succeeding decade.

For the Jordanians, water quality has slowly but continuously declined in the Jordan River Valley. The majority of Jordan's fresh water for Amman comes from the Yarmuk River and wells drilled in nahals and wadis in upper catchments east of the Jordan Valley. Natural springs occur along the rift's bounding faults. The Zarqa River supplies about $25 \%$ of the annual supply and the remainder is collected from side wadis. After the 1994 Treaty of Peace was signed between Jordan and Israel, fresh water began moving through a pipeline from the Sea of Galilee to the East Ghor Canal.

\section{MANAGEMENT OF WATER RESOURCES}

The Israelis have tapped two major aquifers since 1948. The Yarkon/Taninim or "Mountain” Aquifer lies beneath north-central Israel and the West Bank territory of the Palestinian Authority (Fig. 3). 70 to 80\% of the Mountain Aquifer theoretically lies beneath the West Bank region claimed by the Palestinian Authority, as well as 70 to $80 \%$ of the effective recharge area. But the recharged waters flow westward, toward the coastal plain, which belongs to Israel. Since the mid-1960s the Israelis have tapped 25 to $45 \%$ of their agricultural water from this aquifer, causing a gradual but sustained depletion.

The Coastal Aquifer underlies the coastal plain, along the Mediterranean Sea in west central Israel. It is comprised of Plio-Pleistocene age sands and calcareous sandstone. Although the coastal aquifer contributes about 250 million $\mathrm{m}^{3} / \mathrm{yr}$, sea water intrusion has become a nagging problem, 


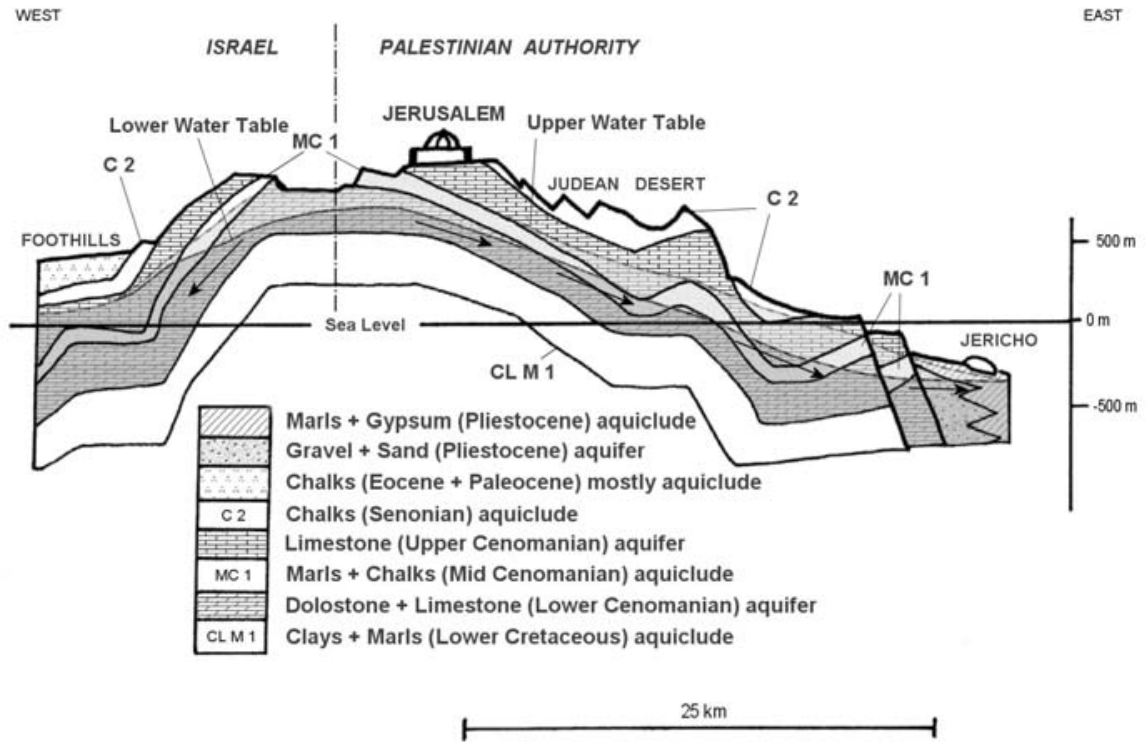

Figure 3 - Cross section through the Yarkon-Taninim, or Mountain Aquifer, in central Israel and the West Bank. This aquifer was steadily reduced between 1948 and 1991. The Israelis have not been able to recharge this aquifer as readily as the younger Coastal Aquifer underling the western coastal lowland.

obviating withdrawals within 40 to $80 \mathrm{~m}$ of the ground surface. The Coastal Aquifer does not extend beneath the West Bank but does lie beneath the entirety of the Gaza Strip.

During the first half century of development (1948-98) the Israelis succeeded in overdrafting the country's water resources between 15 and 20\% beyond the recharge capacity (see lower water table in Fig. 3). Although recharge efforts increased significantly each decade, so did consumption. An additional headache for all three countries has been increasing levels of groundwater pollution, mostly from pesticides, fertilizers, and untreated sewage disposal. In the highly concentrated Gaza Strip (population just over one million), the Coastal Aquifer has become seriously contaminated, requiring additional water and sewage treatment infrastructure to be constructed (Committee on Sustainable Water Supplies, 1999). Loans for these improvements, however, have not been forthcoming from foreign sources, fearful of the region's historic instability.

The Israelis have developed a multi-faceted approach to solve their short and long-term problems with over-utilization of groundwater. Over the past 25 years the Israelis have instituted sweeping conservation measures by employing drip irrigation, later adding fertilizers to create a dual irrigation process they termed "fertigation." Another avenue of research was focused 
on developing salt tolerant species of their agricultural crops. In the 1990s they reported some surprising successes raising crops irrigated with brackish water.

In 1995 the Israelis began recycling 120 million $\mathrm{m}^{3} / \mathrm{yr}$ from the Shafdan Sewage Treatment Plant in Tel Aviv to recharge their Coastal Aquifer (Sitton, 2003). The effluent undergoes secondary treatment before being discharged into spreading basins for one day, then allowed to dry for two to four days. Filtration occurs naturally via percolation through Coastal Aquifer. The Coastal Aquifer is then tapped to provide agricultural water for the western Negev through the Third Negev Pipeline, which presently conveys about 115 million $\mathrm{m}^{3} / \mathrm{yr}$.

Israel's Arab neighbors have spearheaded the employment of desalination for domestic water supply. Until recently, $60 \%$ of the world's desalination capacity lay in Persian Gulf states, with Saudi Arabia accounting for almost a third of annual world production (Starr, 1991). Kuwait, Saudi Arabia, and the United Arab Emirates are almost totally dependent on desalination for their fresh water supply. The Saudis have repeatedly expressed concern over the security of their immense power generation/desalination plants, which are strategically vulnerable to attack or sabotage.

The Israelis recently decided to pursue desalination. By 2004 they hope to complete a reverse osmosis desalinization plant at Ashkelon which will produce 50 million $\mathrm{m}^{3} / \mathrm{yr}$ of fresh water. Israel is in process of designing a second desalination plant with equal capacity. They estimate that the reverse osmosis process can produce cubic meter of water for just US $\$ 0.57$, making it an attractive alternative (the average price their neighbor states pay is about US $\$ 1 / \mathrm{m}^{3}$ ). If these pilot plants are successful, the Israelis hope to expand their desalinization capacity to between 500 to 600 million $\mathrm{m}^{3} / \mathrm{yr}$ by 2012. This could allow additional expansion of their agricultural holdings into irrigable parts of the Negev or compensate them for groundwater withdrawal concessions to the Palestinian Authority.

\section{DISCUSSION}

\subsection{Palestinian Concerns}

When the Declaration of Principles between Israel and the Palestinian Liberation Organization was signed in 1993, a provisional government was established over the West Bank and Gaza Strip known as The Palestinian Authority. West Bank Palestinians obtain their water from pre-1967 wells, but were not permitted to drill any additional wells until the 1993 treaty. Palestinians have always been able to purchase water from Israel's National 
Water Carrier for a charge. While the Palestinians acknowledge that Israel provides requisite water to the West Bank settlements for domestic and industrial use, Israel refuses to increase the volume of their deliveries, which has become a major obstacle in ongoing negotiations. The Palestinians want to draft 200 million $\mathrm{m}^{3}$ per year from the Mountain Aquifer for 10 years (until 2010), and gradually increase these withdrawals to 400 million $\mathrm{m}^{3}$ per year over the succeeding 10 years (2010-2020). They believe that this water is needed for new agricultural crops and their expanding population, which is growing at a rate of $3 \%$ per annum.

Both Jews and Arabs living in Israel use more water per capita than Palestinians in the West Bank or Gaza. Domestic and industrial consumption only account for about 30\% of Israel's water consumption: $70 \%$ of Israel's water is used to support their expansive agricultural enterprise, which includes water-loving crops such as cotton and watermelons, which target the lucrative European market. But Israel's agricultural sector supplies just 5\% of Israel's Gross National Product. Despite this disparity, there is a bipartisan feeling among Israel's leadership that food production should be given a high priority, to better insure self reliance in a world filled with potential enemies.

\subsection{Agreements Forged Between Jordan and Israel}

In 1994 a new water allocation plan was reached between Israel and Jordan as part of the Arava peace treaty, which has not been popular with the Jordanian people (Scham and Lucas, 2001). The treaty promised crucial allocations of water from Israel, cooperative efforts aimed at finding additional resources, establishing increased storage within Jordan, water quality and protection measures and protection of shared groundwater resources, and exchange of hydrologic information between the two countries (Scham and Lucas, 2001).

Jordan's water management policies have evolved as reactions to increasing Israeli development and utilization of the region's extractable water. The Jordanians have employed incremental measures, including dams, canals, deep withdrawal wells and drip-irrigation technology. They have also investigated solar-powered pumping and desalination of brackish groundwater in the northern Arava Valley (south of the Dead Sea) and pumped storage schemes aimed at establishing massive desalination plants near Aqaba.

An example of the frustrations felt by Israel's neighbors is the longawaited al-Wahda Dam on the Yarmuk River, between Syria and Jordan (Fig. 1). Originally conceived in 1955, it was not until 1987 that engineering plans were completed and the search began for funding. The World Bank turned the project down because Israel, Jordan, and Syria could not agree on apportionment, even though Israel only controls $3 \%$ of the watershed. The Bank's established policy is that water must be managed to meet national 
objectives, including social, security, and economic concerns, and that water is an international resource whose apportionment and distribution requires extensive research and international cooperation (Klump, 2002). The bank insists that all entities owning a portion of any watershed must agree on a protocol for development. To date, this has been impossible to achieve in the Jordan River watershed because of the historic enmity between Israel, Jordan, Lebanon, Syria and the Palestinian Authority.

In July 1999 relations between Jordan and Syria had warmed sufficiently that the two countries agreed to build the al-Wahda Dam by circumventing the World Bank, using money from the Jordanian national treasury, the Arab Fund for Economic and Social Development and the Islamic Development Bank. The project has since stalled because of a contractual requirement that $40 \%$ of the project funds be directed to Jordanian and Syrian subcontractors.

\section{CONCLUSIONS}

Israel, Jordan, and the Palestinian Authority are linked by common aquifers that have been exploited to the maximum since the mid-1930s and have recently been subject to overdrafting and contamination. The region's geologic and climatologic settings limit future development by conventional methods. Formal protocols need to be developed for managing these shared water resources. Assistance from international organizations and donor countries has historically been withheld because of perceived instability of the region.

Security concerns have also been an impediment to cooperative resource development by Israel and her neighbor Arab states since 1948. The Israelis are concerned that any above-ground pipeline could serve as a magnet for terrorists, similar to the Los Angeles-Owens River Aqueduct of the 1920s and the repeated attacks on a multinational oil pipeline in Colombia, which has accounted for almost half of the world's terrorist attacks the past few years (152 attacks in 2000 and 178 in 2001).

The Palestinian Authority has the greatest need for developing additional sources of water, but no formal agreement has been reached on this issue in the ongoing negotiations with Israel because of the overpowering concerns about security during the Infantada that began in 1999 .

Development of new water sources will be a fundamental bargaining chip for both Israel and the Palestinian Authority in future negotiations.

The only viable alternatives currently being discussed involve USAID-funded programs, similar to those granted to the Egyptians in 1979 and the Jordanians in 1994, when those countries signed peace treaties brokered by the United States which formally recognized Israel (Starr, 1995). Since 1994 the Palestinians have sought Arab funding for desalination plants, 
but without success. The Israelis have gone forward with construction of desalination plants, which could replace 200 million $\mathrm{m}^{3}$ in groundwater losses from the Mountain Aquifer beneath the Palestinian Authority by 2008, at a cost to Israel of at least US $\$ 114$ million/yr. This figure could triple by 2012, if the Israelis are successful in bringing more desalination plants online. The $3 \%$ annual growth of the Palestinian population demands that something be done to provide additional sources of water or armed conflict will become almost certain (Darwish, 2003).

Over the next century, survivability in the harsh climate of the Middle East will be driven by economic sustainability. The most challenging aspect of expanding populations and infrastructure in Israel, Jordan, and the Palestinian Authority will be potable water. Water infrastructure needs to be constructed ahead of domestic, industrial, and political demands. Water is fundamental to life, both for bodily intake and maintenance of sanitation. Past experience with Middle Eastern countries has shown that sustenance will most likely rely on reverse osmosis desalination of sea water, which requires significant electrical power.

After signing the 1979 peace treaty with Israel, Egyptian President Anwar Sadat said the only reason his country would go ever go to war again would be to protect its water resources (Darwish, 2003). In the $21^{\text {st }}$ century, arid and semi-Arid Middle Eastern nations will be supporting vastly increasing populations, demanding more water than is currently available. These nations will need to employ redundant water supply systems, so the loss of one or two supply lines can be obviated by tapping into parallel or alternative sources, similar to a power grid. The United States will likely continue to serve a key role as the region's treaty broker, facilitating foreign investment in critical engineering infrastructure. Much of that infrastructure will be vulnerable to interdiction by terrorist attacks or overt acts of war. But, these nation's water resources are inevitably intertwined, so that it will be in their mutual interests to cooperate in both the development and common defense of such infrastructure.

\section{REFERENCES}

Beitzel, B.J., 1985, The Moody Atlas of the Bible Lands: Moody Press, Chicago.

Casa, K., 1991, Water: The Real Reason Behind Israeli Occupations: Washington Report on Middle Eastern Affairs: Online Version http://www/washingtonreport.org/backissues/0791/9107626.htm

Committee on Sustainable Water Supplies for the Middle East, 1999, Water for the Future: The West Bank and Gaza Strip, Israel, and Jordan: National Academy Press, Washington, DC.

Darwish, A., 2003, Analysis: Middle East water wars: BBC News, May 30, Online: http://newsvote.bbc.co.uk/mpapps/pagetools/print/news.bbc.co.uk/2/hi/middle_east/294976... 
Efrati, C., 2000, The Successful Failure: The Johnston Water Negotiations: Online Version: http://www.maxwell.syr.edu/maxpages/faculty/gmbonham/2000-Fall-IR-Projects/WebsiteGroup/ICN/Copy\%20of\%20ICNweb/efrati1.htm

Gleick, P., ed., 1993, Water in Crisis: A Guide to the World's Fresh Water Resources: Oxford University Press, New York, 473 p.

Kantor, S., 2001, The National Water Carrier (Ha’ Movil Ha’ Artsi): Online Version: http://research.haifa.ac.il/ eshkol/kantorb.html

Klump, V., 2002, Hydro-Politics Along the Jordan River: Science, Technology \& International Affairs, Georgetown University, School of Foreign Service, Online Version: http://www.georgetown.edu/sfs/programs/stia/students/vol.02/klumpv.htm

Niemi, T.M., Ben-Avraham, Z., and Gat, J.R., 1997, Dead Sea Research-An Introduction : in T.M. Niemi, Z. Ben-Avraham and J.R. Gat, eds., The Dead Sea: The Lake and Its Setting: Oxford University Press, New York, pp. 3-7.

Scham, P.L., and Lucas, R.E., 2001, “Normalization” and “Anti-Normalization” In Jordan: The Public Debate: Middle East Review of International Affairs Journal, v. 5:3 (September), 20 p.

Sitton, D., 2003, Advanced Agriculture as a Tool Against Desertification: Online Version: http://www.mfa.gov.il/mfa/go.asp?MFAH00u70

Starr, J.S., 1991, Water Wars: Foreign Policy, No. 82 (Spring), pp. 17-36.

Starr, J.S., 1995, Covenant Over Middle Eastern Waters: Henry Holt \& Co., New York, 222 p. 